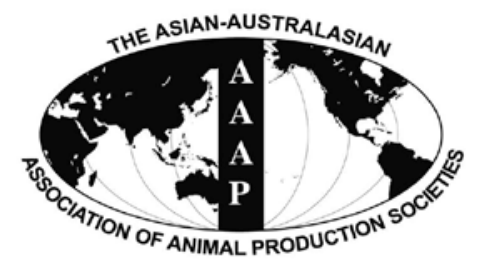

Asian-Aust. J. Anim. Sci.

Vol. 25, No. 2 : 224 - 233

February 2012

www.ajas.info

http://dx.doi.org/10.5713/ajas.2011.11190

\title{
The Limiting Sequence and Proper Ratio of Lysine, Methionine and Threonine for Calves Fed Milk Replacers Containing Soy Protein*
}

\author{
Jianhong Wang, Qiyu Diao**, Yan Tu, Naifeng Zhang and Xiancha Xu \\ Feed Research Institute, Chinese Academy of Agricultural Sciences, \\ Key Laboratory of Feed Biotechnology of Ministry of Agriculture, Beijing, 100081, China
}

\begin{abstract}
The limiting sequence and relative ratio of lysine (Lys), methionine (Met), and threonine (Thr) for calves about 2 mo of age fed milk replacers (MR) containing soy protein are not clearly defined. The objective of the study was to investigate the effect of supplementing MR containing $22 \% \mathrm{CP}$, half from soy protein concentrate (SPC, $40.56 \% \mathrm{CP}$, flour) and half from whey proteins, with Lys, Met, and Thr to estimate amino acid (AA) sequence and their relative ratio for calves about 2 mo of age. A method of partial deduction of AA was adopted. Twenty-four newborn calves (half males and half females, $40.7 \pm 0.9 \mathrm{~kg}$ of BW) were fed 1 of $4 \mathrm{MR}$ diets for $56 \mathrm{~d}(\mathrm{n}=6 / \mathrm{diet})$. The diets were supplemented with all (positive control) or with 2 of the 3 AAs: Lys, Met and Thr, (i.e., PC (22\% CP, 2.34\% Lys, $0.72 \%$ Met and 1.80\% Thr), PC-Lys (22\% CP, 1.64\% Lys, 0.72\% Met and 1.80\% Thr), PC-Met (22\% CP, 2.34\% Lys, $0.50 \%$ Met and $1.80 \% \mathrm{Thr}$ ), and PC-Thr (22\% CP, 2.34\% Lys, $0.72 \%$ Met and $1.26 \% \mathrm{Thr})$ ). Calves were fed thrice daily; starter (20\% CP, $1.03 \%$ Lys, $0.30 \%$ Met and $0.69 \%$ Thr), hay ( $3.23 \%$ CP, $0.29 \%$ Lys, $0.12 \%$ Met and $0.23 \%$ Thr) and water were offered free choice. Starter and hay were only offered beginning on d 36 (after $5 \mathrm{wk}$ ) and d 43 (after $6 \mathrm{wk}$ ), respectively. BW, body size and blood samples measures were taken every two weeks. Three-day total collection of feed refusals, feces, and urine were recorded starting at $\mathrm{d} 33$ and d 54 of age, respectively. From the results, the limiting sequence and relative ratio between the 3 AAs in calves with different diet structures were calculated. The limiting sequence of the 3 AAs were ranked as Lys, Met and Thr; the proper ratio was 100:29:70 for MR-only diet and 100:30:60 for diets consisted of MR, starter and hay. Nitrogen digestion and utilization and nutrient digestibility were negatively affected by AA deletion treatments. From the evidence of this experiment, it did not appear that the AA limiting sequence was selectively altered by differences in diet structures such as would be encountered in practice. The relative ratio between the 3 AAs varied with the offer of starter and hay to calves, and the average ratio was 100:29.5:65 for calves during 2 to 10 wk of age. (Key Words : Limiting Amino Acid, Milk Replacers, Calf, Soy Protein)
\end{abstract}

\section{INTRODUCTION}

The partial replacement of milk sources protein by soy protein in milk replacers (MR) in China has become common in recent years due to economic reasons but such MR may be poor in protein quality due to a deficiency in some limiting amino acids (AAs). Methionine (Met) is often considered to be the first-limiting AA in soy protein (Hays et al., 1959; Williams et al., 1975; Erickson et al., 1989). In addition to Met, MR containing soy protein has also been found to be limiting in lysine (Lys) (Pelaez et al., 1979). The amounts of threonine (Thr) have often been

\footnotetext{
* This research was funded by grants from the China National Science Foundation Committee.

** Corresponding Author : Qiyu Diao. Tel: +86-10-82106055, Fax: +86-10-82106055, E-mail: diaoqiyu@mail.caas.net.cn Received June 21, 2011; Accepted August 15, 2011
}

reported to be lower in soy protein than in milk protein (Erickson et al., 1989). Therefore, addition of these limiting AAs may improve the protein quality of MR containing soy protein. However, recent estimations of the AA requirements were conducted in calves fed milk solely with no starter or hay (Williams and Hewitt, 1979; van Weerden and Huisman, 1985; Toullec, 1989; Gerrits et al., 1997; Hill et al., 2008a). Kanjanapruthipong (1998) found that supplementation of a MR containing soy protein with Lys, Met, and Thr that corresponds to the AA found in milk protein considerably improved the protein quality of that MR for the preruminant calf. However, no attempt was made to establish the sequence of these limiting AAs or to determine the AA requirements in his experiment. All the practices in the studies previously mentioned (Williams and Hewitt, 1979; van Weerden and Huisman, 1985; Toullec, 1989; Gerrits et al., 1997; Kanjanapruthipong, 1998; Hill et 
al., 2008a) for feeding young calves did not conform to commercial conditions in China, where calves are fed not only MR containing milk sources and soy protein but also starter and hay ad libitum. The limiting sequence and relative ratio of these AAs have not been established for calves fed MR containing soy protein under commercial conditions in China. Additionally, the dairy NRC (2001) does not consider individual AA for calves. Therefore, the objectives of this study were to establish the sequence and relative ratio of Lys, Met, and Thr for calves fed MR containing soy protein under commercial conditions, and to investigate the effects of partial deduction of Lys, Met, and Thr on growth performance, concentrations of blood metabolites, and nutrient utilization in Holstein calves.

\section{MATERIALS AND METHODS}

\section{Management of calves and experimental design}

Twenty-four Holstein calves (half males and half females) were acquired from a local commercial diary farm, where all calves received colostrum within $30 \mathrm{~min}$ after birth until $7 \mathrm{~d}$ of age (via nipple bottle), followed by a 5-d adaptation to a PC (positive control) MR (Table 1) from 8 to $13 \mathrm{~d}$ of age.

After the transition period, all calves were moved into individual stalls and randomly assigned to 4 treatments corresponding to $4 \mathrm{MR}$ diets that were different in AA concentrations as follows: PC (MR with well balanced AAs containing $2.34 \%$ Lys, $0.72 \%$ Met and $1.80 \%$ Thr, 22\% CP); PC-Lys (MR with 1.64\% Lys, 0.72\% Met and 1.80\% Thr, 22\% CP); PC-Met (MR with 2.34\% Lys, 0.50\% Met and $1.80 \%$ Thr, 22\% CP); PC-Thr (MR with $2.34 \%$ Lys, $0.72 \%$ Met and $1.26 \%$ Thr, 22\% CP). The concentrations of 3 AAs in PC were chosen based on the reports by Hill (2008a), with either Lys or Met or Thr reduced by 30\% in other 3 treatments, respectively. All MR contained SPC (soy protein concentrate), whey proteins as the protein source, tallow as the fat source, dextrin as the filler and crystal Lys, Met and Thr, with proportions of these ingredients to produce varying contents of Lys, Met and Thr, and consistent protein, fat and energy, along with equal contribution to the protein content of SPC and whey proteins in MR (i.e. soy protein: whey proteins ratio was 50:50). All diets were formulated to provide adequate vitamins and minerals as specified by the NRC (2001) and the data are not listed here. The MR was reconstituted $12.5 \%$ solids and fed at $11 \%$ of BW daily in three equal feedings at 0800, 1400 and 2000. The amount of MR fed was adjusted every two weeks as calves grew. The experiment lasted for $8 \mathrm{wk}$ from September through November of 2009.

Treatments were designed to partially remove a single AA from the basal pattern (i.e. PC treatment) in turn to compare the PC MR with the other treatment diets, on the principle that $\mathrm{N}$ retention is determined by the intake of the first limiting AA, thus, the removal of non-limiting AA should not affect N retention (Wang and Fuller, 1989, 1990).

Fresh water was available at all times. Starter (pellet, 6 $\mathrm{mm})$ composed of ground corn (55.0\%), soybean meal (32.0\%), wheat bran (8.8\%), and a Compound-premix (4.2\%) was fed beginning on d 36. Hay (chopped, Leymus chinensis) was fed beginning on d 43. Dry feed refusals were recorded daily at the evening feeding. Refusals of MR, if any, were recorded at each feeding.

On d 28 and 49, the same 3 calves of each treatment were placed into metabolism stalls for $7 \mathrm{~d}$, respectively. Each period included $4 \mathrm{~d}$ for adaptation followed by $3 \mathrm{~d}$ for total collection (d 33 to 35 and d 54 to 56) of urine and feces.

\section{Health monitoring}

Fecal scores were recorded daily before the morning feeding throughout the trial according to the methods of Hill et al. (2007). Briefly, a 5-point scale was used for fecal scoring. A fecal score of 1 represented firm, well-formed feces, whereas a score of 5 denoted watery feces with abnormal coloring. 20 lactasin ( $\geq 10^{7} \mathrm{cfu} / \mathrm{g}$ ) of each calf were offered to all calves with a fecal score of 3 or greater.

\section{Housing facilities}

Individual calf hutches were placed on a one-story building. The hutches were aligned in two rows east to west, and openings of the hutches faced to the middle of the rows. Each hutch was bedded with 10 to $15 \mathrm{~cm}$ of earth that was topped with a layer of straw.

During the 7-d metabolic trial period, calves were moved from the hutches to metabolism stalls that measured $1.2 \mathrm{~m}$ length $\times 0.6 \mathrm{~m}$ width $\times 1.5 \mathrm{~m}$ height. This size allowed the calf enough room to stand up and lie down, but restricted any movement side to side.

\section{Sampling and analysis of diet, feces and urine}

Total collections of feces and urine were made from $d$ 33 to 35 and from d 54 to 56, respectively. Feces were collected in aluminum pans and dried at $55^{\circ} \mathrm{C}$ for $3 \mathrm{~d}$, ground in a Wiley mill, and then stored in plastic bags until laboratory analysis.

Urine was collected in plastic buckets containing 100 $\mathrm{ml}$ of $50 \%(\mathrm{v} / \mathrm{v}) \mathrm{HCl}$ to minimize the loss of ammonia. The volume of urine was measured, and $1 \%$ of the volume was sampled and combined by calf for each period. The composited urine samples were frozen and stored at $-20^{\circ} \mathrm{C}$ until analysis.

A $50 \mathrm{~g}$ sample of each MR, starter and hay were taken weekly, and the samples were combined by treatment.

Urine samples were analyzed for total Kjeldahl $\mathrm{N}$ 
Table 1. Ingredient and analyzed composition of milk replacers ${ }^{1}$, starter, and hay

\begin{tabular}{|c|c|c|c|c|c|c|c|}
\hline \multirow{2}{*}{ Items } & \multicolumn{4}{|c|}{ Milk replacer } & \multirow{2}{*}{ Starter } & & \multirow{2}{*}{ Hay } \\
\hline & PC & PC-Lys & PC-Met & PC-Thr & & & \\
\hline $\begin{array}{l}\text { Milk replacer ingredient composition } \\
\text { (\% as fed basis) }\end{array}$ & & & & & $\begin{array}{l}\text { Composition of starter } \\
\text { (\% as fed basis) }\end{array}$ & & \\
\hline Soy protein concentrate & 25.90 & 26.90 & 26.00 & 26.40 & Ground corn & 55.00 & \\
\hline Dried whey & 30.00 & 30.70 & 30.00 & 30.20 & Soybean meal & 32.00 & \\
\hline Whey protein concentrate & 17.60 & 18.40 & 17.80 & 18.00 & Wheat bran & 8.80 & \\
\hline tallow & 15.50 & 15.10 & 15.50 & 15.40 & Limestone flour & 1.40 & \\
\hline Compound premix & 3.90 & 3.90 & 3.90 & 3.90 & Calcium hydrogen phosphate & 1.70 & \\
\hline dextrin & 5.10 & 3.80 & 5.10 & 4.70 & Premix $^{2}$ & 0.50 & \\
\hline Lys & 0.83 & 0.06 & 0.82 & 0.80 & Salt & 0.60 & \\
\hline Met & 0.36 & 0.35 & 0.13 & 0.36 & & & \\
\hline Thr & 0.78 & 0.75 & 0.78 & 0.22 & & & \\
\hline \multicolumn{8}{|l|}{ Analyzed nutrient (\% as DM basis) } \\
\hline $\mathrm{DM}$ & 95.92 & 95.96 & 95.83 & 95.81 & 87.63 & & 92.56 \\
\hline $\mathrm{CP}$ & 21.85 & 21.74 & 21.75 & 21.63 & 20.34 & & 3.23 \\
\hline $\mathrm{EE}$ & 14.37 & 14.14 & 14.40 & 14.24 & 2.83 & & 2.20 \\
\hline GE (Mcal/kg) & 4.66 & 4.65 & 4.67 & 4.67 & 3.77 & & 3.12 \\
\hline $\mathrm{Ca}$ & 1.06 & 1.09 & 1.02 & 1.00 & 1.03 & & 0.27 \\
\hline $\mathrm{P}$ & 0.52 & 0.53 & 0.49 & 0.50 & 0.66 & & 0.07 \\
\hline Lys & 2.30 & 1.62 & 2.29 & 2.33 & 1.03 & & 0.29 \\
\hline Met & 0.71 & 0.70 & 0.50 & 0.73 & 0.30 & & 0.12 \\
\hline Thr & 1.79 & 1.81 & 1.78 & 1.25 & 0.69 & & 0.23 \\
\hline \multicolumn{8}{|l|}{ Other AA composition (\% as DM basis) } \\
\hline Asp & 2.29 & 2.38 & 2.30 & 2.33 & 1.45 & & 0.43 \\
\hline Ser & 1.11 & 1.15 & 1.11 & 1.13 & 0.71 & & 0.26 \\
\hline Glu & 3.77 & 3.91 & 3.78 & 3.83 & 2.81 & & 0.56 \\
\hline Gly & 0.63 & 0.66 & 0.64 & 0.64 & 0.78 & & 0.33 \\
\hline Ala & 0.97 & 1.01 & 0.98 & 0.99 & 0.54 & & 0.22 \\
\hline Cys & 0.45 & 0.47 & 0.46 & 0.46 & 0.31 & & 0.09 \\
\hline Val & 1.13 & 1.17 & 1.14 & 1.15 & 0.96 & & 0.54 \\
\hline Ile & 1.14 & 1.19 & 1.15 & 1.16 & 0.62 & & 0.20 \\
\hline Leu & 1.90 & 1.97 & 1.91 & 1.93 & 1.66 & & 0.48 \\
\hline Tyr & 0.67 & 0.70 & 0.67 & 0.68 & 0.44 & & 0.12 \\
\hline Phe & 0.86 & 0.90 & 0.87 & 0.88 & 0.66 & & 0.21 \\
\hline His & 0.66 & 0.69 & 0.67 & 0.67 & 0.71 & & 0.55 \\
\hline Arg & 1.22 & 1.27 & 1.23 & 1.25 & 0.58 & & 0.22 \\
\hline Pro & 1.07 & 1.11 & 1.07 & 1.09 & 1.21 & & 0.38 \\
\hline Total & 17.88 & 18.57 & 17.96 & 18.20 & 13.46 & & 4.59 \\
\hline
\end{tabular}

\footnotetext{
${ }^{1}$ Milk replacers are nationally patented, so only nutrition content is listed.

${ }^{2}$ The premix provided the following per kg of diet: VA 15,000 IU, VD 5,000 IU, VE 50 mg; Fe 90 mg, Cu 22.5 mg, Mn 130 mg, Zn 100 mg, Se 0.3 mg, I $1.0 \mathrm{mg}$, Co $0.5 \mathrm{mg}$.
}

(AOAC, 2000). Samples of feces, MR, starter, and hay were analyzed for DM, OM, total Kjeldahl N, total Ca and total P (AOAC, 2000), total fat by supercritical fluid extraction (TFE2000 Leco Fat Extractor, St. Joseph, MI), and gross energy by bomb calorimetry (Parr 1271, Automatic Bomb Calorimeter, Parr Instrument Company, Moline, IL, USA).

\section{Sampling and analysis of blood metabolites}

Blood was collected into vacuum tubes with no anticoagulant by jugular venipuncture from each calf before morning feeding (after a 12-h fast) every two weeks. The samples were immediately centrifuged at $15,000 \times g$ for 15 min; serum was decanted into individual $2 \mathrm{ml}$ polypropylene tubes, and stored at $-20^{\circ} \mathrm{C}$ for future analyses 
of total protein (kit number 541-2; Sigma-Aldrich Chemical Co., St. Louis, MO, USA), glucose (kit number 315-500; Sigma-Aldrich Chemical Co., St. Louis, MO, USA), and urea N (kit number 535-A; Sigma-Aldrich Chemical Co., St. Louis, MO, USA).

\section{Body growth measurements}

Body weight, withers height (WH), body length (BL), and heart girth (HG) were measured every two weeks. Calculations of ADG of BW and stature measurements were made from these measurements. Rectal temperatures were measured to monitor calf health.

\section{Statistical analysis}

Growth and metabolite data were analyzed using the MIXED procedure of SAS (version 8, SAS Inst. Inc., Cary, NC, USA) with repeated measures. The repeated measure was week, and the subject used in tests was calf within treatment. Observations of $\mathrm{N}$ balance trials were analyzed using the GLM procedure of SAS. An autoregressive covariance structure (AR (1)) was used throughout analyses. Data are reported as least squares means \pm standard errors (SE). Orthogonal polynomial contrasts were used to test for linear and quadratic responses over time. Differences with $\mathrm{p}<0.05$ were considered significant, and differences with $0.05<\mathrm{p}<0.10$ were considered a tendency toward significance. The following model statement was used:

$$
\mathrm{Y}_{\mathrm{ijk}}=\mu+\mathrm{D}_{\mathrm{i}}+\mathrm{W}_{\mathrm{j}}+(\mathrm{DW})_{\mathrm{ij}}+\mathrm{C}_{(\mathrm{i}) \mathrm{k}}+\mathrm{e}_{(\mathrm{ij}) \mathrm{k}}
$$

Where $\mathrm{Y}_{\mathrm{ijk}}=$ dependent variable; $\mu=$ overall mean; $\mathrm{D}_{\mathrm{i}}=$ fixed effect of diet $(i=1, \ldots, 4) ; W_{j}=$ fixed effect of week $(j$ $=2, \ldots, 10) ; \mathrm{C}_{(\mathrm{i}) \mathrm{k}}=$ random effect of calf within diet; $(\mathrm{DW})_{\mathrm{ij}}$ = fixed interaction of diet and week; and $\mathrm{e}_{(\mathrm{ij}) \mathrm{k}}=$ residual error (assumed to be random and independently distributed).

\section{RESULTS AND DISCUSSION}

\section{Formulation and nutrient composition of diets}

The formulated chemical compositions of the $4 \mathrm{MR}$ diets, starter and hay are presented in Table 1. Variation during MR manufacturing resulted in the analyzed content of CP being slightly less than the formulated value of $22 \%$. The contributions of the 3 crystal AAs to protein in $4 \mathrm{MR}$ treatments ranged from 0.79 to $1.51 \%$, due to the different protein contents of the 3 crystal AAs and their varied supplemental amount as designed in MR. The desired CP content and equal proportion of soy protein to whey proteins were produced by varying the relative amounts of dried whey, whey protein concentrate and SPC. To manufacture isocaloric milk replacers, the amount of tallow and dextrin was adjusted in necessity to the main ingredients variation.

Feed intake, growth performance, and general health

There were no differences in MR intake (Table 2). Starter intake in calves fed PC was not different to those fed the other diets, but tended to be higher in PC-Lys than in PC-Met treatment $(p=0.07)$. Similarly, Hill et al. (2008a) observed that starter intake did not change with different Lys or Thr concentrations; but was influenced by Met in the MR with a lower intake associated with $0.68 \%$ Met, which is contradictory to our results. Hay was fed ad libitum from wk 7 for only $3 \mathrm{wk}$, this might be a partial reason for no difference in hay intake between treatments.

Initial BW, BL, WH, and HG were similar among all calves. As expected, calves fed PC had the highest final BW, $\mathrm{BL}, \mathrm{WH}$, and HG, however, there were no significant difference between treatments. Similarly, Hill et al. (2007) observed no differences in body condition scores or hip width for calves fed MR varying in Lys or Met. The effect of diet or diet by week interaction for BW was not significant.

The mean average daily gain (ADG) for the 8-wk experimental period was the highest in PC of all treatments, although the contrast p-values did not achieve statistical significance ( $\mathrm{p}>0.1$ ). Previously, both Jenkins and Emmons (1983) and Kanjanapruthipong (1998) reported that supplementing Lys, Met, Thr, and Ile could increase ADG in calves fed MR containing milk and soy proteins. Improved ADG was also observed when supplementing Lys and Met (Hill et al., 2007) but with no change in ADG when adding Thr in all milk sources formulas (Hill et al., 2008a). Gain to feed ratio was not improved in calves fed PC compared with those fed the other diets $(\mathrm{p}>0.05)$. Calves had access to starter ad libitum since d 36, liquid MR was therefore consumed dominantly by calves. Given the liquid MR has a higher digestibility than starter (Hill et al., 2008b), more efficient gain from wk 4 to 6 compared with other periods was expected.

No calves died during the experimental period. Diarrhea occurred mainly during the first 2 wk of the study, with a $78 \%$ of calves for an average of $8.6 \mathrm{~d}$.

\section{Nitrogen balance and digestibility trial}

Nitrogen utilization data from the balance study from $d$ 33 to 35 and from d 54 to 56 are summarized in Table 3. Calves were fed MR-only diet and diets consisted of MR, starter and hay during the two 3-d period, respectively. N intake did not differ among treatments from d 33 to 35, but tended to be lower in PC-Met compared with PC from d 54 to 56, which was due to calves in PC-Met having consumed less starter than those in PC (Table 2).

Compared with PC, calves fed PC-Lys excreted more 
Table 2. Feed intake, body weight, efficiency of gain, stature measurements, and general health in Holstein calves fed milk replacers varying in Lys, Met and $\mathrm{Thr}^{1}$

\begin{tabular}{|c|c|c|c|c|c|c|c|c|}
\hline \multirow[b]{2}{*}{ Item } & \multicolumn{4}{|c|}{ Treatment $^{2}$} & \multirow[b]{2}{*}{ SEM } & \multicolumn{3}{|c|}{ Contrast p value } \\
\hline & PC & PC-Lys & PC-Met & PC-Thr & & $\begin{array}{l}\text { PC vs. } \\
\text { PC-Lys }\end{array}$ & $\begin{array}{l}\text { PC vs. } \\
\text { PC-Met }\end{array}$ & $\begin{array}{l}\text { PC vs. } \\
\text { PC-Thr }\end{array}$ \\
\hline \multicolumn{9}{|l|}{ Feed intake } \\
\hline $\operatorname{MR}(\mathrm{g} / \mathrm{d})$ & 652 & 633 & 627 & 640 & 55.52 & 0.76 & 0.70 & 0.85 \\
\hline Starter $(\mathrm{g} / \mathrm{d})$ & 417 & 485 & 333 & 397 & 50.09 & 0.40 & 0.30 & 0.80 \\
\hline Hay (g/d) & 201 & 197 & 157 & 201 & 25.49 & 0.90 & 0.21 & 0.99 \\
\hline \multicolumn{9}{|l|}{ Initial body measures } \\
\hline BW (kg) & 40.5 & 40.8 & 40.5 & 40.4 & 1.75 & 0.89 & 0.99 & 0.99 \\
\hline Body length (cm) & 70.8 & 70.9 & 68.8 & 69.8 & 1.43 & 0.96 & 0.27 & 0.57 \\
\hline Wither height (cm) & 76.7 & 76.5 & 75.8 & 75.5 & 2.38 & 0.94 & 0.72 & 0.74 \\
\hline Heart girth (cm) & 86.8 & 88.4 & 86.8 & 86.5 & 2.44 & 0.51 & 1.00 & 0.89 \\
\hline \multicolumn{9}{|l|}{ Final body measures } \\
\hline BW (kg) & 68.6 & 65.9 & 63.2 & 67.4 & 5.04 & 0.69 & 0.42 & 0.86 \\
\hline Body length (cm) & 84.4 & 84.8 & 81.5 & 83.2 & 2.48 & 0.88 & 0.29 & 0.66 \\
\hline Wither height (cm) & 84.1 & 85.3 & 83.2 & 83.9 & 1.45 & 0.49 & 0.62 & 0.94 \\
\hline Heart girth (cm) & 107.4 & 105.6 & 103.4 & 106.1 & 2.41 & 0.52 & 0.16 & 0.64 \\
\hline Average daily gain (g/d) & 503 & 448 & 405 & 483 & 75.26 & 0.57 & 0.32 & 0.83 \\
\hline Gain:feed & 0.48 & 0.42 & 0.41 & 0.47 & 0.05 & 0.35 & 0.25 & 0.88 \\
\hline Average fecal score ${ }^{3}$ & 2.0 & 1.8 & 1.8 & 2.0 & 0.07 & 0.53 & 0.56 & 0.87 \\
\hline Abnormal fecal score days & 8.8 & 8.3 & 8.6 & 8.9 & 1.7 & 0.67 & 0.58 & 0.89 \\
\hline
\end{tabular}

${ }^{1}$ Overall least squares means from $56 \mathrm{~d}$ study.

${ }^{2}$ PC = Milk replacers with 22\% CP, 2.34\% Lys, 0.72\% Met, 1.80\% Thr; PC-Lys = Milk replacers with 22\% CP, 1.64 Lys, 0.72\% Met, 1.80\% Thr; PCMet $=$ Milk replacers with 1.64\% Lys, $0.72 \%$ Met, 1.80\% Thr; PC-Met = Milk replacers with 22\% CP, 2.34\% Lys, 0.50\% Met, $1.80 \%$ Thr; PC-Thr = Milk replacesr with 22\% CP, 2.34\% Lys, 0.72\% Met, 1.26\% Thr.

${ }^{3}$ Fecal score system: 1 = Normal, thick in consistency; 2 = Normal, but less thick; 3 = Abnormally thin but not watery; 4 = Watery; 5 = Watery with abnormal coloring. Abnormal fecal scores were days with scores $>2$.

fecal $\mathrm{N}$ but similar urinary $\mathrm{N}$ during the two periods. Total $\mathrm{N}$ excretion was higher in PC-Lys from d 33 to 35 (p = $0.01)$ and tended to be higher from d 54 to 56 ( $p=0.09)$ than in PC. Fecal and urea N excretion in PC-Met were not different from those in PC, combined with a slightly higher urea N concentration in PC-Met compared with PC, though the difference was not significant (Table 6). $\mathrm{N}$ excretion was not affected by Thr deduction treatment from d 54 to 56, which might have resulted from the starter intake offsetting the lack of Thr in MR to a certain extent. Total N excretion in PC during d 54 to 56 in this study (13.0-17.1 g/d) was lower than that (19.3-34.9 g/d) observed by Hill et al. (2008b) who fed calves with a MR containing higher CP (27-28\%) and EE (20-28\%) contents than ours. As Blome et al. (2003) reported fecal $\mathrm{N}$ excretion increased with $\mathrm{N}$ intake up to $29.4 \mathrm{~g}$ of $\mathrm{N} / \mathrm{d}$, and Bascom et al. (2007) observed an increased $\mathrm{N}$ retention by adding fat to the MR. Compared with gain to feed ratio (0.48) observed in our study, lower or similar gain to feed ratio (0.44) obtained in the abovementioned study (Hill et al., 2008b) with higher dietary CP and EE concentrations demonstrated that adding Lys, Met and Thr to MR not only improved performance, saved protein resources but also minimized the environmental impacts of calves.

Absorbed $\mathrm{N}$ was not affected by treatments, other than it was lower in PC-Met than in PC during d 54 to 56 . N retention in PC tended to be higher compared with PC-Lys for both periods and significantly higher than in PC-Met during d 54 to 56. Compared with PC, absorbed N expressed as a percentage of intake $\mathrm{N}$ (i.e., $\mathrm{N}$ apparent digestibility) was significantly lower for calves fed PC-Lys from d 33 to 35 and from d 54 to 56, and for calves fed PCThr from d 33 to 35 . Retained $\mathrm{N}$ expressed as a percentage of intake $\mathrm{N}$ (i.e., gross efficiency of $\mathrm{N}$ ) was significantly lower for calves fed PC-Lys from d 33 to 35 and from d 54 to 56, and for calves fed PC-Met from d 54 to 56, also for calves fed PC-Thr from d 33 to 35 . Retained N expressed as a percentage of absorbed $\mathrm{N}$ (i.e., apparent biological value of $\mathrm{N}$ : $100 \times(\mathrm{N}$ intake-fecal $\mathrm{N}$-urine $\mathrm{N}) /(\mathrm{N}$ intake-fecal $\mathrm{N})$ ) tended to be lower in PC-Lys and it did not differ significantly among MR treatments.

Apparent biological value of $\mathrm{N}$ refers to the efficiency of use of absorbed $\mathrm{N}$ for growth above maintenance, the above results therefore indicated that there were no 
Table 3. Nitrogen digestion and metabolism in Holstein calves fed milk replacers varying in Lys, Met and Thr

\begin{tabular}{|c|c|c|c|c|c|c|c|c|}
\hline \multirow[b]{2}{*}{ Item } & \multicolumn{4}{|c|}{ Treatment $^{1}$} & \multirow[b]{2}{*}{ SEM $^{2}$} & \multicolumn{3}{|c|}{ Contrast p value } \\
\hline & PC & PC-Lys & PC-Met & PC-Thr & & $\begin{array}{l}\text { PC vs. } \\
\text { PC-Lys }\end{array}$ & $\begin{array}{l}\text { PC vs. } \\
\text { PC-Met }\end{array}$ & $\begin{array}{l}\text { PC vs. } \\
\text { PC-Thr }\end{array}$ \\
\hline \multicolumn{9}{|l|}{$\mathrm{N}$ intake (g/d) } \\
\hline 33 to $35 \mathrm{~d}^{3}$ & 21.66 & 20.44 & 20.69 & 22.16 & 0.67 & 0.58 & 0.66 & 0.82 \\
\hline 54 to $56 d^{4}$ & 48.98 & 47.24 & 39.90 & 40.63 & 1.32 & 0.57 & 0.08 & 0.14 \\
\hline \multicolumn{9}{|l|}{ Fecal N (g/d) } \\
\hline 33 to $35 \mathrm{~d}$ & 4.68 & 6.66 & 5.49 & 6.51 & 0.31 & 0.02 & 0.25 & 0.02 \\
\hline 54 to $56 \mathrm{~d}$ & 6.07 & 8.92 & 6.17 & 6.03 & 0.56 & 0.007 & 0.57 & 0.98 \\
\hline \multicolumn{9}{|l|}{ Urine N (g/d) } \\
\hline 33 to $35 \mathrm{~d}$ & 3.47 & 5.10 & 4.61 & 5.26 & 0.34 & 0.11 & 0.24 & 0.08 \\
\hline 54 to $56 \mathrm{~d}$ & 7.74 & 8.17 & 7.35 & 6.97 & 0.35 & 0.70 & 0.72 & 0.49 \\
\hline \multicolumn{9}{|c|}{ Total N excretion (g/d) } \\
\hline 33 to $35 \mathrm{~d}$ & 8.15 & 11.75 & 10.10 & 11.77 & 0.50 & 0.01 & 0.03 & 0.01 \\
\hline 54 to $56 \mathrm{~d}$ & 13.80 & 17.09 & 13.51 & 13.00 & 0.70 & 0.09 & 0.82 & 0.65 \\
\hline \multicolumn{9}{|c|}{ Absorbed N (g/d) } \\
\hline 33 to $35 \mathrm{~d}$ & 16.98 & 13.78 & 15.20 & 15.65 & 0.64 & 0.11 & 0.35 & 0.48 \\
\hline 54 to $56 \mathrm{~d}$ & 42.44 & 37.60 & 35.51 & 36.89 & 1.20 & 0.17 & 0.04 & 0.12 \\
\hline \multicolumn{9}{|c|}{ Retained N (g/d) } \\
\hline 33 to $35 \mathrm{~d}$ & 13.25 & 8.69 & 10.60 & 10.39 & 0.90 & 0.08 & 0.26 & 0.23 \\
\hline 54 to $56 \mathrm{~d}$ & 34.71 & 29.43 & 28.16 & 29.92 & 1.06 & 0.09 & 0.03 & 0.12 \\
\hline \multicolumn{9}{|c|}{ Absorbed $\mathrm{N}$ of intake $\mathrm{N}(\%)$} \\
\hline 33 to $35 \mathrm{~d}$ & 78.25 & 67.47 & 73.52 & 70.30 & 1.44 & 0.01 & 0.11 & 0.02 \\
\hline 54 to $56 \mathrm{~d}$ & 87.69 & 80.60 & 85.25 & 86.06 & 1.18 & 0.04 & 0.19 & 0.60 \\
\hline \multicolumn{9}{|c|}{ Retained N of intake N (\%) } \\
\hline 33 to $35 \mathrm{~d}$ & 62.03 & 42.16 & 50.70 & 45.70 & 3.08 & 0.02 & 0.14 & 0.05 \\
\hline 54 to $56 \mathrm{~d}$ & 71.72 & 63.21 & 67.45 & 69.76 & 1.25 & 0.03 & 0.10 & 0.57 \\
\hline \multicolumn{9}{|c|}{ Retained N of absorbed N (\%) } \\
\hline 33 to $35 \mathrm{~d}$ & 79.06 & 62.64 & 68.95 & 64.79 & 3.24 & 0.10 & 0.28 & 0.14 \\
\hline 54 to $56 \mathrm{~d}$ & 81.76 & 78.52 & 79.15 & 81.05 & 0.80 & 0.24 & 0.25 & 0.79 \\
\hline
\end{tabular}

${ }^{1}$ PC = Milk replacers with 22\% CP, 2.34\% Lys, 0.72\% Met, 1.80\% Thr; PC-Lys = Milk replacers with 22\% CP, 1.64\% Lys, 0.72\% Met, 1.80\% Thr; PCMet = Milk replacers with 22\% CP, 2.34\% Lys, 0.50\% Met, 1.80\% Thr; PC-Thr = Milk replacers with 22\% CP, 2.34\% Lys, 0.72\% Met, 1.26\% Thr.

${ }^{2}$ SEM for $\mathrm{n}=3$; highest listed. ${ }^{3}$ Calves fed MR-only diet. ${ }^{4}$ Calves fed diets consisted of MR, starter and hay.

significant differences among MR treatments in the efficiency of $\mathrm{N}$ utilization by calves for growth. However, compared with PC, gross efficiency of $\mathrm{N}$ was significantly lower with partial deduction of Lys and Thr from d 33 to 35, probably because of the $\mathrm{N}$ imbalance. The latter values may be more relevant for use in determining effects of nutrition on $\mathrm{N}$ utilization in calves, which was similar to the discovery of Blome et al. (2003). Terosky et al. (1997) reported an apparent biological value of $\mathrm{N}$ of $73.7 \%$ for a MR based entirely on whey proteins with $20.7 \%$ CP. Diaz et al. (2001) reported an apparent biological value of $\mathrm{N}$ ranging from 57.0 to $70.0 \%$ for a MR formulated by allmilk protein with $30 \%$ CP fed at different rates. In the study of Blome et al. (2003), results were $50.7 \%$ for a MR based entirely on whey proteins $(22.9 \% \mathrm{CP})$. Our values for the apparent biological value of $\mathrm{N}$ are higher than all the above studies even when half of the MR protein was provided by soy protein, probably because of essential AAs (i.e., Lys,
Met and Thr) being added to the MR in our study.

Using the results of the nitrogen balance trial, it is possible to express the responses in $\mathrm{N}$ retention to the intake of individual AA. Figure 1 shows the rate of $\mathrm{N}$ retention in relation to daily $\mathrm{N}$ intake. The proportion of the 3 essential AAs was calculated using the simple linear model (Wang and Fuller, 1989, 1990). The slope (Table 4) describes the proportional effect of removing an AA from the PC; e.g. for Lys (33 to 35 d), (100-66.4)/(100-69.6) which is 1.104. Amongst these $3 \mathrm{AA}$, a higher slope for the Lys deletion treatment (PC-Lys) means that this AA was the first limiting AA in PC treatment. To calculate the proportion of each AA that could be removed from the PC amino acid pattern to make it equally limiting to Lys, it was assumed that when all AA are equally limiting they should all have the same slope. Thus, the required amount of Met (33 to 35 d), for example, can be calculated as 


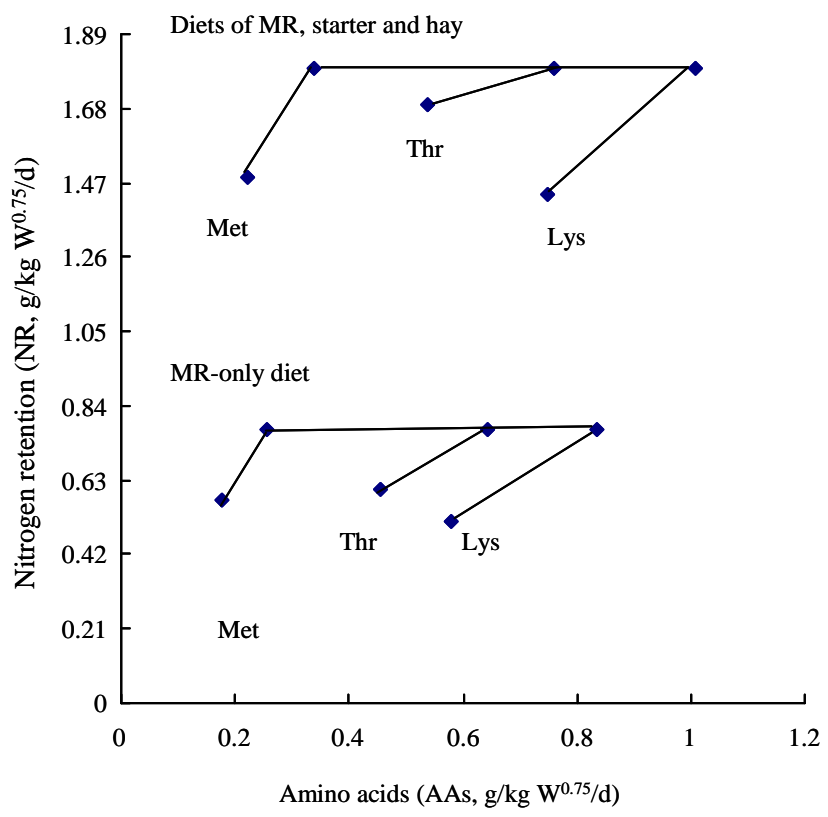

Figure 1. The effects of deleting 30\% of Lys, Met, Thr from PC treatment on nitrogen retention in milk replacers in calves. PC = milk replacers with 22\% CP, 2.34\% Lys, $0.72 \%$ Met, $1.80 \%$ Thr; PC-Lys = Milk replacers with 22\% CP, 1.64\% Lys, 0.72\% Met, $1.80 \%$ Thr; PC-Met $=$ Milk replacers with $22 \%$ CP, $2.34 \%$ Lys, $0.50 \%$ Met, $1.80 \%$ Thr; PC-Thr $=$ Milk replacers with 22\% CP, 2.34\% Lys, $0.72 \%$ Met, $1.26 \%$ Thr.

$$
\begin{aligned}
\text { Slope of Lys } & =(100-66.4) /(100-69.6) \\
& =(100-74.2) /(X-69.3)
\end{aligned}
$$

$\mathrm{X}=0.93$, thence $1.00-0.93=0.07$ of Met could be removed from that in the $\mathrm{PC}$ to make Met co-limiting with Lys. In PC (33 to 35 d), Met intake was $257 \mathrm{mg}$ and Lys intake was $835 \mathrm{mg} / \mathrm{kg} \mathrm{W}^{0.75} / \mathrm{d}$, so the amount required to make it equally limiting to Lys was $257 \times 0.93=239 \mathrm{mg}$. Thus, the ideal ratio between Met and Lys was calculated 28.51:100. Based on the principle of the method of AA partial deduction, the limiting sequence of the 3 AAs were ranked as Lys, Met and Thr; the proper ratio was 100:29:70 for period from 33 to $35 \mathrm{~d}$ and 100:30:60 for period from 54 to $56 \mathrm{~d}$ in calves.

The deduction proportion ranged from 20 to $25 \%$ in growing pigs (Wang and Fuller, 1989, 1990), and with the exception of Arg, essential AA contents were 17 to 32\% lower in MR containing soy protein than in MR containing skim milk protein (Kanjanapruthipong, 1998). Besides, considering that the ad libitum feeding of calves with starter in our study may reduce the gap originally designed, we widened the deducting proportion to $30 \%$. In this experiment, each specific AA was made first limiting in turn in the AA deletion treatments (Figure 1).

The limiting sequence of the 3 AAs coincided with the results of $\mathrm{N}$ retention, $\mathrm{N}$ apparent digestibility, and gross efficiency of $\mathrm{N}$, which were most affected by partial deduction of Lys, secondly Met and then Thr. These results agree with Abe et al. (1997) who found that Lys was the first-limiting AA for calves roughly less than 3 mo of age when fed corn and corn gluten meal diets. On the other hand, our findings are contradictory to the observations by

Table 4. Calculation of the limiting sequence and proper ratio between Lys, Met and Thr for calves fed milk replacers containing soy

\begin{tabular}{|c|c|c|c|c|c|c|c|c|}
\hline \multirow{2}{*}{ Treatment } & \multicolumn{4}{|c|}{ Amino acid intake (mg/kg W $\left.\mathrm{W}^{0.75} / \mathrm{d}\right)$} & \multicolumn{4}{|c|}{ Relative to the PC } \\
\hline & $\mathrm{NR}^{1}$ & Lys & Met & Thr & NR & Lys & Met & Thr \\
\hline \multicolumn{9}{|l|}{33 to $35 d^{2}$} \\
\hline PC & 0.771 & 835 & 257 & 643 & 1.000 & 1.000 & 1.000 & 1.000 \\
\hline PC-Lys & 0.512 & 581 & 255 & 637 & 0.664 & 0.696 & 0.992 & 0.991 \\
\hline PC-Met & 0.572 & 835 & 178 & 642 & 0.742 & 1.000 & 0.693 & 0.998 \\
\hline PC-Thr & 0.604 & 844 & 260 & 455 & 0.783 & 1.011 & 1.012 & 0.708 \\
\hline \multicolumn{9}{|l|}{54 to $56 \mathrm{~d}^{3}$} \\
\hline PC & 1.795 & 1,007 & 339 & 759 & 1.000 & 1.000 & 1.000 & 1.000 \\
\hline PC-Lys & 1.436 & 750 & 324 & 735 & 0.800 & 0.745 & 0.956 & 0.968 \\
\hline PC-Met & 1.484 & 911 & 223 & 694 & 0.827 & 0.905 & 0.658 & 0.914 \\
\hline PC-Thr & 1.689 & 938 & 309 & 539 & 0.941 & 0.931 & 0.912 & 0.710 \\
\hline \multirow{2}{*}{ Treatment } & \multicolumn{4}{|c|}{33 to $35 \mathrm{~d}$} & \multicolumn{4}{|c|}{54 to $56 \mathrm{~d}$} \\
\hline & Slop $^{4}$ & $\mathrm{P}^{5}$ & $\mathrm{AA}^{6}$ & $\mathrm{R}^{7}$ & Slop & $\mathrm{P}$ & AA & $\mathrm{R}$ \\
\hline PC-Lys & 1.104 & 1.00 & 835 & 100.00 & 0.784 & 1.00 & 1,007 & 100.00 \\
\hline PC-Met & 0.840 & 0.93 & 239 & 28.51 & 0.506 & 0.88 & 298 & 0.30 \\
\hline PC-Thr & 0.741 & 0.90 & 581 & 69.60 & 0.204 & 0.79 & 600 & 0.60 \\
\hline
\end{tabular}
protein

${ }^{1}$ Nitrogen retention (g/kg W $\left.{ }^{0.75} / \mathrm{d}\right) .{ }^{2} 33$ to $35 \mathrm{~d}$ MR-only diet. ${ }^{3} 54$ to $56 \mathrm{~d}$ diets of MR, starter and hay.

${ }^{4}$ Slope $=$ Effect of the limiting amino acid intake on nitrogen retention, calculated as proportional change in nitrogen retention/ proportional change in nitrogen retention.

${ }^{5} \mathrm{P}=$ Proportion of amino acid in the PC treatment required to maintain the same nitrogen retention as the PC treatment; calculation explained in text.

${ }^{6} \mathrm{AA}=$ Amino acid (mg/kg W ${ }^{0.75} / \mathrm{d}$ ) required to maintain the same nitrogen retention as the PC treatment, calculated as amino acid intake in PC $\times \mathrm{P}$.

${ }^{7} \mathrm{R}=$ Ratio between these 3 amino acids relative to Lys. 
Abe et al. (1998) that Met was the first-limiting and Lys was probably the second-limiting AA for weaned calves less than 11 wk of age on corn and soybean meal diets. The difference may be partially due to the diet composition (e.g., low Lys in corn while low Met in soybean meal). The Thr to Lys ratio was lower for calves fed MR, starter, and hay (i.e., from 54 to 56 d) than calves fed MR only (i.e., from 33 to 35 d). For calves about 2 mo of age, the average ratio among the 3 AAs was Lys 100, Met 29.5 and Thr 65, close to 100:26:66 (Lys:Met:Thr) obtained by a mechanistic model estimation by Gerrits et al. (1997), and to 100:29:65 (Lys:Met:Thr) estimated from responses of $\mathrm{N}$ apparent digestibility, $\mathrm{N}$ retention, plasma urea, and plasma Lys by Williams and Hewitt (1979). These findings verify that determining AA requirements by partial deduction is feasible for calves about 2 mo of age.

The apparent digestibility (Table 5) of DM, OM, and EE was significantly lower for calves fed PC-Lys from d 33 to 35 than the calves fed PC. The apparent p digestibility tended to be lowered by partial deduction of Met $(p=0.1)$. Otherwise, there were no differences in nutrient digestion among MR treatments. It seemed that Lys deficiency exerted greater influences on the apparent digestibility of DM, OM, and EE compared with that of the other two AAs, which was consistent with Lys being the first-limiting AA among the 3 AAs in PC diet.

\section{Blood metabolites}

Concentrations of metabolites in serum sampled before feeding are summarized in Table 6 . There were no differences ( $p>0.05$ ) among diets, and the effect of diet by week interaction was not significant for total protein (TP). However serum TP concentrations increased in a linear manner from wk 2 to wk 10 (50.71 to $63.83 \pm 2.56 \mathrm{mg} / \mathrm{dl}$; p $=0.0054$ ) in all calves.

$\mathrm{TP}$ is the maximum composition of solid contents in serum, including albumin and globulin which are associated with nutrition and immunity, respectively. The effects of dietary CP levels on serum TP concentration have been reported (Terosky et al., 1997; Bartlett et al., 2006; Daniels et al., 2008), but few reported about AAs: Li (2008) reported that either excess or lack of Lys lowered serum TP concentrations in calves. Decreased plasma protein is a well-known consequence of protein malnutrition (Swenson, 1993; Bartlett et al., 2006). However, the values for calves fed 4 different diets in our study were undifferentiated, maybe the deduction amount of the 3 AAs was too small to cause a difference in serum TP concentration.

Neither diet nor week nor the interaction of diet $\times$ week significantly affected serum glucose concentration. It has

Table 5. Apparent digestibility (\%) of nutrient in Holstein calves fed milk replacers varying in Lys, Met and Thr

\begin{tabular}{|c|c|c|c|c|c|c|c|c|}
\hline \multirow[b]{2}{*}{ Item } & \multicolumn{4}{|c|}{ Treatment $^{1}$} & \multirow[b]{2}{*}{$\mathrm{SEM}^{2}$} & \multicolumn{3}{|c|}{ Contrast p value } \\
\hline & PC & PC-Lys & PC-Met & PC-Thr & & $\begin{array}{l}\text { PC vs. } \\
\text { PC-Lys }\end{array}$ & $\begin{array}{l}\text { PC vs. } \\
\text { PC-Met }\end{array}$ & $\begin{array}{l}\text { PC vs. } \\
\text { PC-Thr }\end{array}$ \\
\hline \multicolumn{9}{|l|}{$\mathrm{DM}$} \\
\hline 33 to $35 \mathrm{~d}^{3}$ & 85.26 & 79.80 & 83.99 & 82.59 & 0.87 & 0.03 & 0.56 & 0.23 \\
\hline 54 to $56 \mathrm{~d}^{4}$ & 88.10 & 83.65 & 86.17 & 87.12 & 0.94 & 0.13 & 0.49 & 0.71 \\
\hline \multicolumn{9}{|l|}{$\mathrm{OM}$} \\
\hline 33 to $35 \mathrm{~d}$ & 88.29 & 83.83 & 89.04 & 86.61 & 0.63 & 0.01 & 0.37 & 0.23 \\
\hline 54 to $56 \mathrm{~d}$ & 88.92 & 85.05 & 89.90 & 88.47 & 0.97 & 0.18 & 0.72 & 0.87 \\
\hline \multicolumn{9}{|l|}{ GE } \\
\hline 33 to $35 \mathrm{~d}$ & 89.41 & 87.25 & 90.75 & 90.50 & 0.34 & 0.47 & 0.65 & 0.72 \\
\hline 54 to $56 \mathrm{~d}$ & 87.86 & 86.61 & 93.38 & 92.19 & 0.25 & 0.82 & 0.34 & 0.45 \\
\hline \multicolumn{9}{|l|}{$\mathrm{EE}$} \\
\hline 33 to $35 \mathrm{~d}$ & 95.79 & 91.94 & 94.72 & 93.47 & 0.58 & 0.02 & 0.44 & 0.11 \\
\hline 54 to $56 \mathrm{~d}$ & 95.82 & 93.95 & 95.51 & 94.63 & 0.50 & 0.25 & 0.84 & 0.45 \\
\hline \multicolumn{9}{|l|}{$\mathrm{Ca}$} \\
\hline 33 to $35 \mathrm{~d}$ & 47.72 & 33.64 & 44.70 & 39.10 & 3.56 & 0.22 & 0.78 & 0.44 \\
\hline 54 to $56 \mathrm{~d}$ & 71.02 & 56.17 & 63.71 & 60.65 & 3.11 & 0.13 & 0.43 & 0.27 \\
\hline \multicolumn{9}{|l|}{$\mathrm{P}$} \\
\hline 33 to $35 \mathrm{~d}$ & 73.63 & 69.18 & 71.03 & 70.71 & 1.49 & 0.37 & 0.59 & 0.55 \\
\hline 54 to $56 \mathrm{~d}$ & 89.59 & 82.55 & 79.56 & 80.38 & 2.02 & 0.23 & 0.10 & 0.13 \\
\hline
\end{tabular}

${ }^{1}$ PC = Milk replacers with 22\% CP, 2.34\% Lys, 0.72\% Met, 1.80\% Thr; PC-Lys = Milk replacers with 22\% CP, 1.64\% Lys, 0.72\% Met, 1.80\% Thr; PCMet = Milk replacers with 22\% CP, 2.34\% Lys, 0.50\% Met, 1.80\% Thr; PC-Thr = Milk replacers with 22\% CP, 2.34\% Lys, 0.72\% Met, 1.26\% Thr.

${ }^{2}$ SEM for $\mathrm{n}=3$; highest listed.

${ }^{3}$ Intake of MR-only diet for this period was 567, 568, 565 and 559 g/d DM for PC, PC-Lys, PC-Met and PC-Thr, respectively.

${ }^{4}$ Total intake of MR, starter and hay for this period was 1,774, 1,698, 1,508, 1,454 g/d DM for PC, PC-Lys, PC-Met and PC-Thr, respectively. 
Table 6. Effects of diets 1, and time on serum metabolite concentrations in Holstein calves

\begin{tabular}{|c|c|c|c|c|c|c|c|c|c|}
\hline \multirow{2}{*}{ Item } & \multicolumn{5}{|c|}{ Week } & \multirow{2}{*}{ SEM $^{2}$} & \multicolumn{3}{|c|}{ Test of fixed effects, p-value } \\
\hline & 2 & 4 & 6 & 8 & 10 & & Diet & Week & Diet×week \\
\hline \multicolumn{10}{|c|}{ Total protein( $\mathrm{mg} / \mathrm{dl})$} \\
\hline PC & 53.83 & 53.17 & 55.50 & 59.50 & 62.83 & 3.42 & 0.8043 & $<0.001^{\mathrm{a}}$ & 0.2027 \\
\hline PC-Lys & 49.50 & 50.17 & 54.17 & 59.67 & 63.83 & & & & \\
\hline PC-Met & 50.83 & 53.33 & 49.05 & 50.02 & 66.17 & & & & \\
\hline PC-Thr & 48.67 & 49.83 & 53.33 & 58.17 & 62.50 & & & & \\
\hline \multicolumn{10}{|c|}{ Glucose (mmol/L) } \\
\hline PC & 5.00 & 4.86 & 4.42 & 4.67 & 5.43 & 0.71 & 0.6009 & 0.4517 & 0.3084 \\
\hline PC-Lys & 5.01 & 4.44 & 4.18 & 4.65 & 5.47 & & & & \\
\hline PC-Met & 4.64 & 4.13 & 6.50 & 6.74 & 5.15 & & & & \\
\hline PC-Thr & 4.54 & 4.48 & 4.27 & 4.33 & 5.59 & & & & \\
\hline \multicolumn{10}{|c|}{ Urea N (mmol/L) } \\
\hline PC & 2.74 & 3.02 & 2.57 & 2.55 & 3.15 & 0.80 & 0.1108 & 0.5688 & 0.2296 \\
\hline PC-Lys & 2.92 & 3.19 & 2.95 & 2.87 & 2.87 & & & & \\
\hline PC-Met & 2.77 & 3.71 & 5.63 & 5.98 & 3.24 & & & & \\
\hline PC-Thr & 2.88 & 2.69 & 2.46 & 2.80 & 2.82 & & & & \\
\hline
\end{tabular}

been reported that, with the development of the rumen, metabolic rate was regulated to the adult state and serum glucose level declined gradually (Bunting et al., 2000). Daniels et al. (2008) found that, calf starter promoted rumen development and hence hastened the transition from an essentially monogastric animal (high blood glucose) to a functional ruminant (low blood glucose). Therefore, serum concentration of glucose increased during the period of wk 6 to 8 for calves fed PC-Met, probably reflecting a reduced development of the rumen compared with the calves fed the other 3 diets, which were also consistent with less starter intake in PC-Met.

Serum urea $\mathrm{N}$ concentration was not influenced by any fixed effects $(\mathrm{p}>0.05)$. The diets used in this experiment were designed to differ in AAs. Serum urea $\mathrm{N}$ as markers for AA metabolism would be expected to be affected by diet, however, no alteration in the value was determined in current study. Terosky et al. (1997), Smith et al. (2002), and Daniels et al. (2008) also noted no change in urea $\mathrm{N}$ contents about imposed dietary treatments or over time, which is similar to our observation.

\section{IMPLICATIONS}

Supplementing milk replacers containing soy protein with synthetic lysine, methionine and threonine significantly improved nitrogen digestion and utilization in calves, and minimized the environmental impacts. These large responses to added amino acid demonstrate the importance of formulating milk replacers for lysine, methionine and threonine, and not just crude protein, while demanding more soy protein as an alternative protein. The present study showed that the average ratio of lysine, methionine and threonine was found to be 100:29.5:65 and the limiting sequence of the 3 amino acids was ranked as lysine, methionine and threonine for calves fed milk replacers containing soy protein under commercial conditions.

\section{ACKNOWLEDGEMENTS}

The authors thank the staff at the commercial dairy farm for assistance with feeding, weighing and blood sampling. Sincere thanks are extended to K. Deng for valuable comments to the manuscript.

\section{REFERENCES}

Abe, M., T. Iriki and M. Funaba. 1997. Lysine deficiency in postweaned calves fed corn and corn gluten meal diets. J. Anim. Sci. 75:1974-1982.

Abe, M., T. Iriki, M. Funaba and S. Onda. 1998. Limiting amino acids for a corn and soybean meal diet in weaned calves less than three months of age. J. Anim. Sci. 76:628-636.

AOAC. 2000. Official methods of analysis.17th ed. Association of Offical Analytical Chemists, Arlington, Virginia, USA.

Bartlett, K. S., F. K. McKeith, M. J. VandeHaar, G. E. Dahl and J. K. Drackley. 2006. Growth and body composition of dairy calves fed milk replacers containing different amounts of protein at two feeding rates. J. Anim. Sci. 84:1454-1467.

Bascom, S., R. E. James, M. L. McGilliard and M. E. Van 
Amburgh. 2007. Influence of dietary fat and protein on body composition of Jersey bull calves. J. Dairy Sci. 90:5600-5609.

Blome, R. M., J. K. Drackley, F. K. McKeith, M. F. Hutjens and G. C. McCoy. 2003. Growth, nutrient utilization, and body composition of dairy calves fed milk replacers containing different amounts of protein. J. Anim. Sci. 81:1641-1655.

Bunting, L. D, T. A. Tarifa, B.T. Crochet, J. M. Fernandez, C. L. DePew and J. C. Lovejoy. 2000. Effects of dietary inclusion of chromium propionate and calcium propionate on glucose disposal and gastrointestinal development in dairy calves. J. Anim. Sci. 83:2491-2498.

Daniels, K. M., S. R. Hill, K. F. Knowlton, R. E. James, M. L. McGilliard and R. M. Akers. 2008. Effects of milk replacer composition on selected blood metabolites and hormones in preweaned Holstein heifers. J. Dairy Sci. 91:2628-2640.

Diaz, M. C., M. E. Van Amburgh, J. M. Smith, J. M. Kelsey and E. L. Hutten. 2001. Composition of growth of Holstein calves fed milk replacer from birth to 105-kilogram body weight. J. Dairy Sci. 84:830-842.

Erickson, P. S., D. J. Schauff and M. R. Murphy. 1989. Diet digestibility and growth of Holstein calves fed acidified milk replacers containing soy protein concentrate. J. Dairy Sci. 72: 1528-1533.

Gerrits, W. J. J., J. France, J. Dijkstra, M. W. Bosch, G. H. Tolman and S. Tamminga. 1997. Evaluation of a model intergrating protein and energy metabolism in preruminant calves. J. Nutr. 127:1243-1252.

Hays, V. W., V. C. Speer, P. A. Hartman and D. V. Catron. 1959. The effect of age and supplemental amino acids on the utilization of milk and soya proteins by the young pig. J. Nutr. 69:179-184.

Hill, S. R., K. F. Knowlton, K. M. Daniels, R. E. James, R. E. Pearson, A. V. Capuco and R. M. Akers. 2008b. Effects of replacer composition on growth, body composition, and nutrient excretion in preweaned Holstein heifers. J. Dairy Sci. 91:3145-3155.

Hill, T. M., H. G. Bateman II, J. M. Aldrich, R. L. Schlotterbeck and K. G. Tanan. 2008a. Optimal concentration of lysine, methionine, and threonine in milk replacers for calves less than five weeks of age. J. Dairy Sci. 91:2433-2442.

Hill, T. M., J. M. Aldrich, R. L. Schlotterbeck and H. G. Bateman II. 2007. Amino acids, fatty acids, and fat sources for calf milk replacers. The Professional Animal Scientist. 23:401-408.

Jenkins, K. J. and D. B. Emmons. 1983. Fortification of calf milk replacers with amino acids in free form or plastein-bound. Can. J. Anim. Sci. 63:893-903.
Kanjanapruthipong, J. 1998. Supplementation of milk replacers containing soy protein with threonine, methionine, and lysine in the diets of calves. J. Dairy Sci. 81:2912-2915.

Li Hui. 2008. Effect of protein level and source on nutrient utilization and gastrointestinal characteristics in early-weaning calves. PhD Thesis. Chinese Academy of Agricultural Sciences, Beijing.

National Research Council. 2001. Nutrient requirements of dairy cattle. $7^{\text {th }}$ rev. ed. National Academy. Press, Washington, DC, USA.

Pelaez, R. and D. M. Walker. 1979. Milk replacers for preruminant lambs: limiting amino acids in two soybeans protein isolates determined with a changeover design. Aust. J. Agric. Res. 30:125-134.

SAS Institute Inc. 1999. SAS users guide, Version 8.1. SAS Institute Inc., Cary, North Carolina, USA.

Smith, J. M., M. E. Van Amburgh, M. C. Diaz, M. C. Lucy and D. E. Bauman. 2002. Effect of nutrient intake on the development of the somatotropic axis and its responsiveness to GH in Holstein bull calves. J. Anim. Sci. 80:1528-1537.

Swenson, M. J. 1993. Physiological properties and cellular and chemical constituents of blood. Pages 41-43 in Duke's Physiology of Domestic Animals. 11th ed. M. J. Swenson and W. O. Reece, ed. Cornell Univ. Press, Ithaca, NY, USA.

Terosky, T. L., A. J. Heinrichs and L. L. Wilson. 1997. A comparison of milk protein sources in diets of calves up to eight weeks of age. J. Dairy Sci. 80:2977-2983.

Toullec, R. 1989. Veal calves. Pages 109-119 in Ruminant Nutrition-Recommended Allowances and Feed Tables (Ed. R. Jarrige). INRA, London, UK.

van Weerden, E. J. and J. Huisman. 1985. Amino acid requirement of the young veal calf. J. Anim. Physiol. Anim. Nutr. (Berl.) 53:232-244.

Wang, T. C. and M. F. Fuller. 1989. The optimum dietary amino acid pattern for growing pigs. 1. Experiments by amino acid deletion. Br. J. Nutr. 62:77-89.

Wang, T. C, and M. F. Fuller. 1990. The effect of the plane of nutrition on the optimum dietary amino acid pattern for growing pigs. Anim. Prod. 50:155-164.

Williams, A. P. and D. Hewitt. 1979. The amino acid requirements of the preruminant calf. Br. J. Nutr. 41:311-318.

Williams, A. P. and R. H. Smith. 1975. Concentrations of amino acids and urea in the plasma of the preruminant calf and estimation of the amino acid requirements. Br. J. Nutr. 33:149158. 